Natalia Solvyeva

\title{
SOME ASPECTS OF TAX REFORM IN THE RUSSIAN FEDERATION
}

Tax law is the youngest and most dynamically developing sub-branch of Russian financial law.

In July 1998 the first part of the Tax Code of the Russian Federation came into force. The system of taxes and fees as well as general principles of taxation in the Russian Federation were determined there. In August, 2000 the second part of the Tax Code containing the order of the collection of particular taxes came into force.

The Tax Code replaced the multitude of tax laws which were not systematized and compatible. Undoubtedly, the codification of tax legislation has mainly advantages, however, it is necessary to mark obvious incoherence in a number of tax regulations.

The present article discusses some aspects of the regulation of tax privileges and tax deductions.

A tax privilege has been defined for the first time in Article 56 of the Tax Code. The soviet and post-soviet period legislation did not provide for the definition of a tax privilege, although the post-period legislation specified the list of tax privileges.

The Tax Code, which is in force now, defines the tax privilege as an advantage granted to certain categories of taxpayers and fee payers and provided by the tax and fee legislation, on the contrary to other taxpayers and fee payers; such advantages include the possibility not to pay a tax or a fee or to pay them in a limited amount.

Tax privilege is an optional element of taxation, its assignment depends on the legislator's discretion, which could be concluded from the analysis of the Tax Code articles and confirmed by the decisions of the Constitutional Court of the Russian Federation.

The second part of the Tax Code provides the tax privileges for only two taxes: property tax on enterprises and common social tax. Therefore, it might be concluded 
that the legislator tends to reduce the number of tax privileges assigned to particular taxes.

The analysis of the Tax Code articles proves, however, that the legislator has substituted the terms, which can be illustrated by the following example.

The chapter "Income tax" of the Tax Code provides four kinds of the tax deductions: standard tax deductions, social tax deductions, property tax deductions and professional tax deductions.

All of the tax deductions mentioned reduce the tax base for the categories of taxpayers stipulated by tax legislation. Each type of tax deduction is carried out in a special way, thus it could be assumed, on the basis of the essence of the tax deductions, that such tax deductions are tax privileges.

Moreover, a tax privilege has following essential attributes which distinguish it from other legal privileges.

- a tax privilege is always an advantage for a certain category of taxpayers in comparison to all other taxpayers;

- a tax privilege is always legal - based on the rules of law;

- a tax privilege is granted only to certain category of taxpayers. A category of taxpayers could be defined as a certain group of taxpayers sharing any common criterion (attribute) which distinguishes it from other taxpayers ${ }^{1}$. Some authors remark that the presence of a category of taxpayers to which advantages on tax payment are granted is exactly the core of the definition of privilege ${ }^{2}$.

- a tax privilege always takes the form of special rule of law, which is applied only under the conditions determined by the legislation, "it is the subject to priority application in the determination of a particular person's tax duty"3;

- a tax privilege is a right of taxpayers; according to the Tax Code, taxpayers have a right to refuse to use the tax privilege or to suspend it for one or several tax periods.

All the attributes of the tax privileges listed above are applicable and observed in tax deductions for income tax. It is also worth pointing out that the concept of tax deductions is a novelty in the tax legislation.

1 М. Титова, Налоговые льготы. Автореферат, St. Petersburg 2004, p 19.

2 А. Калинин, И. Николаев, О состоянии системы налоговых льгот "Финансовые и бухгалтерские консультации" 2004, № 1, р 42.

3 А. Зимин, Правовой режим налоговых льгот “Налоговые споры: теория и практика” 2005, № 11(23), р. 26. 
Income tax deductions, however, are not the only tax deductions provided by the Tax Code.

Tax deductions for value added tax (VAT) and excises are regulated in Chapter 21 and Chapter 22 of the Tax Code. Tax deductions for indirect taxes mentioned above are certain amounts determined by the Tax Code for all taxpayers; they reduce the amount of the tax payable to the budget.

Obviously the rule imposed on all taxpayers cannot be defined as a tax privilege. In fact, the assignment of the tax privilege for all taxpayers means a change of general rules of tax collection.

Moreover, the rules on tax deductions for indirect taxes are not special rules which establish which taxpayers are privileged (which constitutes the essence of the tax privilege) but their application is the only possible order to calculate indirect taxes for all taxpayers.

The contradiction between tax deduction for indirect taxes and attributes of tax privilege allows to draw a conclusion that such tax deductions are not tax privileges but another element of the taxation.

The application of tax deductions established for indirect taxes which taxpayers make is a necessary action to calculate the amount of the tax payable to the budget.

As for the VAT, for example, the Tax Code provides that the amount of tax payable to budget shall be calculated on the basis of results of each tax period as the overall amount of the tax calculated according to the Tax Code, reduced by the amount of tax deductions fixed in the Tax Code (Article 173 of the Tax Code). Similar regulations are provided for excises. Therefore, it seems justifiable to relate tax deductions for indirect taxes to such an element of taxation as the order of tax calculation.

The Tax Code of the Russian Federation does not define the order of tax calculation. In the literature the order of tax calculation is stipulated as the procedure of calculation of the amount of the tax on the basis of application of the fixed tax rate to the tax base that was set during the tax period ${ }^{4}$.

Moreover, tax deductions for indirect taxes are essential elements of the order of calculation of indirect taxes; without tax deductions indirect taxes will lose their significance and it will not be possible to calculate and pay them.

The place of tax deductions in the mechanism of indirect taxes confirms the above statement. 
Indirect taxes are often perceived as consumption taxes that are included in the price of goods (services) and paid by an ultimate consumer ${ }^{5}$.

Ms. Kudryashova E. points out that transposition of the tax is the most popular criterion underlying the definition of indirect taxes now and before ${ }^{6}$.

Transposition of the tax can be defined as repartition of the tax between juridical subject of the tax (taxpayer) and virtual payer of the tax (tax bearer) ${ }^{7}$.

VAT and excises are indirect taxes, the amount of which should be transposed to an ultimate consumer. Such transposition is possible if the law provides the opportunity to offset the tax that is paid for goods and services used in production.

According to the Tax Code, tax deductions for indirect taxes are amounts that are paid by taxpayers and the tax payable to budget is reduced by these amounts. The offset of the tax is neither more nor less than the result of excess of amount of tax deductions over the amount of tax payable (Article 176 and Article 203 of the Tax Code). Therefore, it could be affirmed that the transposition of the tax mentioned above occurs only by means of tax deductions.

Thus tax deductions for indirect taxes are not only an element of the order of the tax calculation but also the mechanism that allows to perform the transposition of the tax to an ultimate consumer and by that to assure the existence of indirect tax.

Unlike tax deductions for income tax (which are considered tax privileges and consequently an optional element of taxation) tax deductions for indirect taxes are an obligatory element of the order of tax calculation. As illustrated above, their assignment depends on the essence of indirect taxes and cannot depend on the legislator's discretion.

It could, therefore, be concluded that the Tax Code provides identical, legal term "tax deduction" for the legal concepts which are totally different by its legal nature and essence.

Such a situation could be explained in two ways:

1. The legislator could proceed from the polysemy of the legal "tax deduction". Some authors consider inadmissible to use polysemantic terms ${ }^{8}$. Nevertheless, both juridical theory and practice accepts the existence of legal terms which have several meanings, although, it was repeatedly marked that polysemantic terms lead to illegibility and vagueness of legal regulations. In any case, there

\footnotetext{
Г. Горина, Косвенные налоги и цены: Учебное пособие, М 2002, р. 88.

Е. Кудряшова, Правовые аспекты косвенного налогообложения: теория и практика, М. 2006, р 13.

Е. Кудряшова, Правовые аспекты косвенного налогообложения: теория и практика, М. 2006, р. 23.

Язык закона/ Под ред. А. С. Пиголкина - М 1990, р 107.
} 
is an obligatory requirement to have normative definition of polysemantic terms in the text of the law. The legislator has not specified that.

2. The legislator has made a technical, legal mistake which was the designation of different legal concepts by the same legal term. This explanation seems to be the most probable. The technical, legal mistake could be described as a kind of legislative mistake that represents the break of rules of legislative technique by participants of legislative procedure as a result of their honest mistake; such mistakes are reflected negatively in the quality of legislative act $^{9}$.

Actually, there is an impression that the legislator used the term "tax deduction" in the cases stated above proceeding only from the common meaning of the word "deduction", understood as any reduction not taking into consideration the essence of each tax deduction.

In the author's opinion, the confirmation between the form and content of the legal terms and concepts used in the Tax Code of the Russian Federation is required in such a situation. 


\section{Streszczenie}

Niniejszy artykuł prezentuje niektóre aspekty reformy podatkowej w Federacji Rosyjskiej, głownie w odniesieniu do przywilejów i potrąceń podatkowych. Pomimo, że obecnie obowiązujący Kodeks Podatkowy wprowadził wiele pozytywnych zmian w systemie podatkowym, pozostaje jednak niespójny $\mathrm{z}$ wieloma regulacjami podatkowymi. Wspomniane przywileje i potrącenia są przykładem takich niespójności. Potrącenia podatkowe są nowością w ustawodawstwie podatkowym i występują w podatkach dochodowym, od wartości dodanej oraz akcyzowym.

Celem artykułu jest przedstawienie różnych konstrukcji prawnych tej samej instytucji - ,potrąceń podatkowych”. 